УДК 543.552

\title{
DESIGN, RHEOLOGY AND MICROSTRUCTURE OF FOOD-GRADE EMULSION-BASED SYSTEMS FOR DELIVERY OF VITAMIN D
}

\begin{tabular}{|c|c|c|}
\hline \multicolumn{3}{|c|}{$\begin{array}{l}\text { S.M. Gubsky }{ }^{*, a},{ }^{\prime} \text { O.F. Aksonova, }{ }^{*, b}, \text { V.V. Evlash }{ }^{*, c}, \\
\text { A.S. Batrak }\end{array}$} \\
\hline \multicolumn{3}{|c|}{$\begin{array}{l}\text { * Kharkiv State University of Food Technology and Trade, Department of Chemistry, Mi } \\
\text { and Hygiene of Nutrition, } 333 \text { Klochkivska str., } 61051 \text { Kharkiv, Ukraine }\end{array}$} \\
\hline \multicolumn{3}{|c|}{$\begin{array}{l}\dagger \text { V.N. Karazin Kharkiv National University, School of Chemistry, Department of } \\
\text { Chemistry, Svobody sq., 4, } 61022 \text { Kharkiv, Ukraine }\end{array}$} \\
\hline a) & $\square$ sergey.m.gubsky@gmail.com & (1) https://orcid.org/0000-0003-0358-8682 \\
\hline b) & 凶eaksonova@gmail.com & (1) https://orcid.org/0000-0003-4666-9271 \\
\hline c) & Mevlashvv@gmail.com & (1) https://orcid.org/0000-0002-8525-8937 \\
\hline d) & М.s.batrak.khnu@gmail.com & (1) https://orcid.org/0000-0002-8331-7163 \\
\hline e) & \lagutaanna22@gmail.com & (1) https://orcid.org/0000-0002-0736-2923 \\
\hline & Donkalugin@gmail.com & 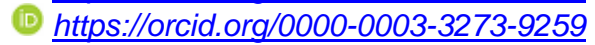 \\
\hline
\end{tabular}

The fortification of food with vitamin $D$ has several limitations because this group of fat-soluble compounds may degrade or undergo undesirable changes during technologic processing and storage of food. The purpose of this study was to investigate emulsions for vitamin $D_{3}$ delivery in commercial foods. Oil-inwater (o/w) emulsions stabilized by mixture of various proteins (whey protein isolate (WPI), skimmed milk powder (SMP) and vegan protein isolate (VPI)) as emulsifiers and carboxymethylcellulose as thickening agent were used. The shear stress and effective dynamic viscosity of the emulsions in the wide range of shear rates were experimentally determined. By approximating experimental flow curves using the powerlaw model, the values of the consistency coefficient and flow behavior index were obtained, which made it possible to classify the emulsions as systems with pseudoplastic flow.

Within the framework of the structural approach, the rheological data were analyzed on the basis of the generalized rheological model of Casson. The contributions to the process of viscous flow calculated from the experimental data from the integral characteristics of associates of droplets and individual particles during their hydrodynamic interaction made it possible to explain the effect of changing the viscosity of emulsions from the nature of the emulsifier used.

The zeta potential values determined by the dynamic light scattering method indicate the existence of a strong repulsive force as a factor for the stability of emulsions. The sign of the potential and its magnitude indicate the process of adsorption on the surface of fat droplets molecule of protein. The presence of a peak of flocculated particles in the histograms of the particle size distribution is explained by the presence of nonadsorbing polysaccharides, which are capable of the generation of aggregated emulsion structures through depletion flocculation.

Regardless of the choice of the type and nature of the protein emulsifier - animal or plant origin, all studied systems were stable and can be considered for use as emulsion-based delivery systems of vitamin D. From an economic point of view, it is advisable to use dry milk as an emulsifier. The resulting emulsions can be used as a basis for the production of vitamin $\mathrm{D}_{3}$-fortified foods, in particular for dairy products.

Keywords: rheology, protein, emulsion, delivery system, vitamin D, structural approach.

\section{Introduction}

Vitamin $\mathrm{D}(\mathrm{VD})$ is a fat-soluble vitamin. It supplements are available in two forms: vitamin $\mathrm{D}_{2}$ (ergocalciferol) and vitamin $\mathrm{D}_{3}$ (cholecalciferol). Both are also naturally occurring forms that are produced in the presence of the sun's ultraviolet rays, but only $\mathrm{D}_{3}$ in animals, including humans [1]. VD production in the skin is the primary natural source of vitamin $\mathrm{D}_{3}$, but many people have insufficient levels. Today, according to medical reports, the majority of the world's population is deficient in the vitamin $\mathrm{D}_{3}[2,3]$. This problem is inherent in the population of Ukraine [4].

Vitamin $\mathrm{D}_{3}$ is known to play an important role in bone health (calcium and phosphorus metabolism) [5], play a role in muscle development and epidemiologic data suggest its benefits cardiovascular mortality, hypertension, colorectal cancer, multiple sclerosis, type 1 diabetes, immune function, and inflammation [6-8]. More detailed information on biochemical and physiological aspects can be found in the monograph [9]. In 2020, close attention to VD was due to both the problems of the global food market and publications related to the spread of the COVID-19 virus [10]. Analysis of statistical 
medical data has shown the important role of this vitamin in the regulation of the immune system in viral infections [11]. According to the authors [12], VD consumption can lead to a decrease in severe complications of COVID-19, suppress hypercytokinemia, while increasing innate immunity and avoiding a significant increase in adaptive immunity. In report [13] present preliminary evidence of a link between VD deficiency in humans and the severity of COVID-19 disease. The authors concluded in favor of the intake of this vitamin in the human body as a potential additional strategy to prevent the incidence of COVID-19 or reduce the severity of the disease.

Since VD deficiency is a widespread health problem, functional foods fortified with this vitamin have been attracting more and more consumer attention around the world in recent years [10]. A detailed overview of such products, including country of origin information, is given in [3]. Fortification is considered the most effective among the available medical interventions, but requires close attention to studying the interaction of the introduced component with components of the food matrix of products. Ignoring this factor can lead to the loss of the added enrichment component during processing and/or storage of the food product. From a chemical point of view, VD is sensitive to oxidation processes due to the presence of double bonds in the structure. In addition, factors such as light, oxygen and high temperature can cause isomerization and degradation of the vitamin, leading to the formation of its inactive forms. All these problems must be solved for the development of an effective and budgetary technology for introducing vitamin VD into food products.

Many foods are manufactured as emulsions. That is why, a promising solution is the introduction of vitamin VD in emulsions by encapsulation [14,15]. In this way the VD can be protected from conditions that lead to its degradation [3]. In this case, various emulsions should be considered as emulsion-based delivery systems of bioactive compound into the human body and they are of undoubted interest for the food industry [16]. In recent years, particular interest has been attracted by the use of nanotechnology in this area $[17,18]$. However, an emulsion in the macro- and nanoscale range is a thermodynamically unstable system that is capable of destabilizing over time by sedimentation, flocculation, coalescention, Ostwald ripening and phase separation [19]. In addition, droplet size directly depends on the stability of the emulsion, as well as on the optical, rheological and sensory properties [20]. It has been shown that, smaller droplets can usually be formed when the viscosity ratio (the viscosity of the oil phase to the viscosity of the aqueous phase) is close to unity. This indicates that knowledge of the rheological properties of the material is becoming one of the important factors for the development of technological processes for creating food emulsions [21] and would help to improve the economic production of high-quality products [22].

Thus, the effective process of creating a food product as emulsion-based delivery systems of VD is determined by two main factors: the stability of emulsions as the ability of an emulsion to resist changes to its properties over time and the absence of vitamin degradation in the food matrix. This should take into account the fact that the delivery systems should meet food-grade standards, both in the formulation and in production methods [23].

In the last decade, the research has addressed with growing intensity the development of foodgrade delivery systems for VD. As an example, some summarized data from these studies, important for the design of the developed emulsion, are presented in Table 1.

As can be seen from Table 1, even on such a small number of the above studies, in experimental development, a fairly wide variety of types of emulsions, methods of their preparation and emulsion components are used. But when choosing one or another methodology for obtaining emulsion-based delivery systems as a commercial product, an economic criterion related to the cost of production becomes important. Taking into account all the above factors, in the section Emulsion structure design and sampling, the choice of the objects of this study is justified.

The aim of this work was to study (i) the formation process and the stability of vegetable oil-inwater emulsions as potential as emulsion-based delivery systems of VD (in form of $\mathrm{D}_{3}$ ) in commercial foods and (ii) rheological and microscopic parameters variation of such emulsions prepared in the laboratory from the type of protein emulsifier.

\section{Emulsion structure design and sampling}

The above analysis of the literature data made it possible to optimize the design of the studied emulsions using the authors' sample as a prototype [24]. But instead of rapeseed oil, sunflower oil was 
used as the fat phase with VD introduced into it. Such a replacement for a future commercial product, firstly, is quite logical for economic reasons, given the price of both oils and the region of production (Kharkiv Oblast, Ukraine). Secondly, it should be taken into account that in [25] the fact of an increase in the preservation of VD with a decrease in the size of droplets was noted. Replacing rapeseed oil (dynamic viscosity at $26{ }^{\circ} \mathrm{C}$ is $59.2 \mathrm{mPa} \cdot \mathrm{s}$ [28]) by sunflower oil (dynamic viscosity at $26{ }^{\circ} \mathrm{C}$ is $48.8 \mathrm{mPa} \cdot \mathrm{s}$ [28]) should lead to a decrease in the droplet size of the fat phase. The generation of small droplets during homogenization depends on the ratio of the viscosity of the dispersed phase to that of the continuous phase [29]. And thirdly, sunflower oil is more stable to oxidation due to the lower content of polyunsaturated and monounsaturated fatty acids in fatty acids composition [28].

Table 1. Some emulsion-based systems for delivery of vitamin D

\begin{tabular}{|c|c|c|c|c|c|c|}
\hline Туре* & $\mathrm{MH}^{* *}$ & $\begin{array}{l}\text { Oil phase } \\
(\% \mathrm{w} / \mathrm{w})\end{array}$ & $\begin{array}{l}\text { Emulsifier } \\
(\% \mathrm{w} / \mathrm{w})\end{array}$ & $\begin{array}{l}\text { Stabilizer, } \\
(\% \mathrm{w} / \mathrm{w})\end{array}$ & $\begin{array}{l}\text { Main results (emulsion } \\
\text { stability and vitamin D } \\
\text { degradation) }\end{array}$ & Ref. \\
\hline $\begin{array}{c}\mathrm{C} \\
\mathrm{O} / \mathrm{W}\end{array}$ & HSH & $\begin{array}{l}\text { rapeseed } \\
\text { oil } \\
(40)\end{array}$ & $\begin{array}{l}\text { whey protein } \\
\text { (2) }\end{array}$ & $\begin{array}{l}\text { carboxymethyl } \\
\text { cellulose } \\
(0.75)\end{array}$ & $\begin{array}{c}\text { creaming stability } 100 \% \\
\text { and retention of vitamin D } \\
93 \% \text { after } 7 \text { days of storage } \\
\text { at } 4^{\circ} \mathrm{C} \text { in the dark }\end{array}$ & [24] \\
\hline $\begin{array}{c}\mathrm{C} \\
\mathrm{O} / \mathrm{W}\end{array}$ & $\mathrm{MF}$ & $\begin{array}{l}\text { medium- } \\
\text { chain tri- } \\
\text { glycerides } \\
\text { (4) }\end{array}$ & $\begin{array}{l}\text { gum arabic } \\
(7), \text { maltodex- } \\
\text { trin }(2), \\
\text { whey protein } \\
(0.5), \\
\text { soy protein } \\
(4)\end{array}$ & & $\begin{array}{l}\text { the highest protection of } \\
\text { vitamin D }(70-85 \%) \text { at } \\
25^{\circ} \mathrm{C} \text { after } 30 \text { days; the } \\
\text { minimum size of particles } \\
\text { obtained were as } \\
132-468 \mathrm{~nm} \text {; the minimum } \\
\text { amount of vitamin D would } \\
\text { be oxidized in smaller } \\
\text { droplets }\end{array}$ & [25] \\
\hline $\begin{array}{l}\mathrm{ML} \\
\mathrm{O} / \mathrm{W}\end{array}$ & $\mathrm{S}$ & $\begin{array}{l}\text { canola oil } \\
\text { (7) }\end{array}$ & $\begin{array}{c}\text { soy lecithin } \\
\text { and tween } 80 \\
\text { with ratio } 2: 3 \\
\text { (4) }\end{array}$ & & $\begin{array}{l}\text { droplet growth ratio was } \\
0.141 \text { after } 14 \text { days of stor- } \\
\text { age; vitamin D retention } \\
76 \% \text {; values for droplet size } \\
\text { was } 112.36 \mathrm{~nm}\end{array}$ & [26] \\
\hline $\begin{array}{c}\mathrm{P} \\
\mathrm{O} / \mathrm{W}\end{array}$ & HP & $\begin{array}{l}\text { soybean } \\
\text { oil } \\
(10)\end{array}$ & $\begin{array}{l}\text { nanofibrillated } \\
\text { cellulose } \\
(0.3-0.7)\end{array}$ & & $\begin{array}{l}\text { The emulsions were stable } \\
\text { to temperature, most } \mathrm{pH} \\
\text { values ( } 3 \text { to } 7 \text { ); good stabil- } \\
\text { ity to long-term storage, } \\
\text { with little evidence of } \\
\text { creaming; retention of vi- } \\
\text { tamin } \mathrm{D}>94 \%\end{array}$ & [27] \\
\hline
\end{tabular}

* Type of emulsion: $\mathrm{C}$ - conventional; $\mathrm{ML}$ - multilayer emulsion; $\mathrm{P}$ - Pickering.

** MH (Method of homogenization): HSH - high-speed (rotor-stator); MF - microfluidization;

S- sonication; HP - high pressure

Emulsions $(\mathrm{o} / \mathrm{w})$ with different emulsifiers were used for research. In food technologies, surfactants are widely used as emulsifiers, in particular, protein emulsifiers (Table 1), which are adsorbed on the surface of the droplet, reducing the interfacial tension. In the process of stabilization of emulsions, the molecular properties of proteins are manifested: structure, surface hydrophobicity and molecular weight, which makes possible the formation of small droplets. In addition, milk and vegetable proteins are natural emulsifiers [20]. Most edible emulsions usually contain a combination of protein and polysaccharides. The latter compounds are used as a thickening component and stabilizer. When certain environmental conditions are created ( $\mathrm{pH}$, temperature, ionic strength), the interaction of these components can be used as a factor for obtaining an emulsion and optimizing its stability [30,31].

There are two alternative ways in which emulsion droplets can be stabilized by a mixture of protein and polysaccharide [32]. In this study, we used simultaneous adsorption principle by analogy with 
research [33]. According this method, first procedure is to prepare a mixed solution of the protein and $\mathrm{CMC}$, and then use the resulting protein-polysaccharide complex as the emulsifying agent during homogenization. But it was taken into account that the WP-CMC interaction will not occur at a $\mathrm{pH}$ close to neutral. Therefore, in emulsions stabilized with a mixture of WP and CMC, the polysaccharide molecules remain unabsorbed on the oil drop. But research has shown [20] CMC can increase the stability of emulsions by increasing the viscosity or gelation of the aqueous phase. As a result, the oil droplets of the emulsion are blocked by the structure of the resulting gel, which prevents delamination [31]. It should also be noted the effect of carboxymethylcellulose on the stability of emulsions under conditions that simulate real conditions of digestion in the gastrointestinal tract [33].

Taking into account the information given in the literature sources discussed above, in this study, samples of emulsions were used as objects, the composition of which is given in Table 2. The emulsions were made in triplicate at room temperature and the batch size was $200 \mathrm{~g}$.

Table 2. Formulations of o/w emulsions weighing $100 \mathrm{~g}$

\begin{tabular}{|c|c|c|c|}
\hline \multirow[b]{2}{*}{ Emulsion } & \multicolumn{2}{|c|}{ Aqueous phase } & \multirow[b]{2}{*}{$\begin{array}{l}\text { Oil phase, } \\
(\% \mathrm{w} / \mathrm{w})\end{array}$} \\
\hline & $\begin{array}{c}\text { Emulsifier, } \\
(\% \mathrm{w} / \mathrm{w})\end{array}$ & $\begin{array}{c}\text { Stabilizer, } \\
(\% \mathrm{w} / \mathrm{w})\end{array}$ & \\
\hline EWP & WPI (2.0) & \multirow{3}{*}{$\mathrm{CMC}(0.75)$} & \multirow{3}{*}{$\begin{array}{l}\text { sunflower oil (40.0) with } \\
100.0 \mu \mathrm{g} \text { of vitamin } \mathrm{D}_{3}\end{array}$} \\
\hline EMP & $\operatorname{SMP}(2.0)$ & & \\
\hline EVP & VPI (2.0) & & \\
\hline
\end{tabular}

\section{Experimental Section}

Reagent. Vitamin $\mathrm{D}_{3}$ powder (800 I.U./g) was purchased from Susin Biotech Co., LTD (Hefei, China). Sodium carboxymethylcellulose (CMC) (reagent purity $\geq 99,5 \pm 3 \%$, viscosity of $2 \%(\mathrm{w} / \mathrm{w})$ solution at $25{ }^{\circ} \mathrm{C}$ equals $1000-3000 \mathrm{mPa}$ ) was received from Carl ROTH GmbH Co (Karisruhe, Germany). Emulsion was prepared using double distilled water.

Materials. Raw materials were purchased from the following suppliers: skimmed milk powder (content w/w: $1.5 \%$ fat, $32.0 \%$ protein) (PJSC Milk Canning Factory, Kupyansk, Ukraine); sunflower oil TM Oleina refined, deodorized, frozen (w/w: $0.05-0.06 \%$ moisture, no more $12 \%$ saturated fat; 14-35\% monounsaturated fat; 50-75\% polyunsaturated fat) (Suntrade Subsidiary Enterprise, Ukraine). Commercially available food additives Whey Protein QNT $(78.3 \% \mathrm{w} / \mathrm{w}$ whey protein isolate) and Vegan Protein QNT (pea protein isolate and rice protein with total protein amount $77.12 \% \mathrm{w} / \mathrm{w}$ ) (QNT, Belgium) was procured from the local supermarket in the city of Kharkiv, Ukraine.

Preparation of solution. A solution of a mixture of sodium carboxymethylcellulose and skimmed milk $(\mathrm{CMC}+\mathrm{WPI})$ with concentration $\mathrm{CMC}(0.75 \% \mathrm{w} / \mathrm{w})$ and protein $(2 \% \mathrm{w} / \mathrm{w})$ was prepared by dispersing the required amount of component in distilled water (per $100 \mathrm{~g}$ final solution) under continuous stirring (1000 rpm) using a magnetic stirrer.

Preparation of emulsion. The oil-in-water $(\mathrm{o} / \mathrm{w})$ emulsions stabilized by proteins and CMC were prepared as described [24]. Method is to prepare a mixed solution of the biopolymers, and then use the resulting protein-polysaccharide complex as the emulsifying agent during homogenization.

Initially, for the manufacture of the studied emulsions, aqueous solutions of CMC $(2 \% \mathrm{w} / \mathrm{w})$ and solutions of necessary protein components with a mass protein concentration of $10 \% \mathrm{w} / \mathrm{w}$ for samples were prepared from weighed portions of the corresponding components according to formulation. The nonsheared mixture were stirred and mixed at an appropriate ratio for at least $1 \mathrm{~h}$. The $\mathrm{pH}$ of the mixture was adjusted to 7 using $0.1 \mathrm{M} \mathrm{NaOH}$. The emulsion was made by dispersing the oil phase (sunflower oil) in the necessary protein and CMC mixture for $5 \mathrm{~min}$ at $24000 \mathrm{rpm}$ using an the IKA Disperser T 25 digital Ultra-Turrax (IKA, Staufen, Germany) homogenizer combined with disperser $\mathrm{S} 25 \mathrm{~N}$. The vitamin $\mathrm{D}_{3}$ solution in ethanol was added to the mixture after 5 minutes after homogenization to prevent vitamin oxidation by air.

Speed mixer for homogenization. In addition to the EMP emulsion, which was made by dispersing the oil phase at $24000 \mathrm{rpm}$, an emulsion EMP1 of the same composition was used in the experiment. But it was made by homogenizing the fat phase in an aqueous mixture of SMP and CMC at $11000 \mathrm{rpm}$ using high-speed mixer (Hungary). 
pH stability. All emulsions were freshly prepared and then adjusted to $\mathrm{pH}$ values 7 using $0.1 \mathrm{M}$ $\mathrm{NaOH}$. This $\mathrm{pH}$ value makes it possible to obtain the smallest particle size of the dispersed phase, the zeta-potential value is less $-30 \mathrm{mV}$ and retention (\%) of vitamin $\mathrm{D}_{3}$ at or above $90 \%$ using fatty phases of different nature [34].

Measurements. The apparent viscosity of emulsions was determined by using a rotation viscometer OFITE Model 900 Viscometer (OFI Testing Equipment, Inc., USA). The device operated with a true Couette coaxial cylinder with combination standard F1.0 spring (constant 386), rotor R1 (radius $1.8414 \mathrm{~cm}$ ) and bob B1 (radius $1.7245 \mathrm{~cm}$, height $3.8 \mathrm{~cm}$ ) in variable speed range 1-1000 rpm with speed accuracy $0.001 \mathrm{rpm}$. All measurements were carried out at shear rate constant $1.7023 \mathrm{~s} / \mathrm{rpm}$, overall instrument constant 300 and maximum shear stress $0.0168 \mathrm{mN} / \mathrm{cm}^{2}$. Calibration Fluid Batch: 100 cP NIST N 132-80 (OFI Testing Equipment, Inc., USA) was used to calibrate of viscometer at a temperature of $298 \mathrm{~K}$. The procedure for calibrating the viscometer, measurements, and calculation of the effective dynamic viscosity were performed as in [35]. The combination of spring-rotor-bob used in the study allowed measurements on the rotary viscometer described above to the shear stress value $157 \mathrm{~Pa}$. This meant the possibility of measurements in the range shear rate $1-1200 \mathrm{~s}^{-1}$ for dispersed medium MED and emulsions EWP и EMP1. For the EMP and EVP emulsions, for this reason, data were obtained only in the range shear rate $1-136 \mathrm{~s}^{-1}$ and $1-42 \mathrm{~s}^{-1}$, respectively.

The particle size distributions and zeta potential of the emulsions were measured by dynamic light scattering (DLS) distribution using a particle and molecular size analyzer (Zetasizer Nano ZS, Malvern Instruments Ltd., Melvin, UK). This instrument determines the particle size from intensity-time fluctuations of a laser beam (a $4.0 \mathrm{~mW}$ He-Ne laser with a wavelength of $633 \mathrm{~nm}$ ) scattered from a sample at an angle of $173^{\circ}$. Each individual measurement was an average of 10 runs. The particle size and $\xi$-potential was measured for the fresh emulsions immediately after $1 \mathrm{~h}$ of production. The samples were diluted with double distillated water until a diluted solution viscosity of $1.9 \mathrm{mPa} \cdot \mathrm{s}$ was reached (approximately 1: 100-150 dilution ratio). For calculation of particle size and $\xi$-potential were used values of optical parameters as follow: refractive index of 1.469 for the dispersed phase; refractive index of 1.333 for the continuous phase and droplet absorbance of 0.01 . The particle size measurements are reported as the average and standard deviation of measurements made on two freshly prepared samples, with two readings made per sample. The Smoluchowski's equation used for zetapotential calculations.

Stability of emulsion were measured according [36]. A graduated tube with a volume of $10 \mathrm{ml}$ was filled up to the upper mark with an emulsion. Then placed in centrifuges and centrifuged for 5 minutes at $1500 \mathrm{rpm}$. Then this tube was placed in boiled water for 3 minutes and then centrifuged again for 5 minutes.

Creaming index (CI) of emulsion were measured as in [25]. An amount of $25 \mathrm{ml}$ of samples was placed in a tube and stored at $25{ }^{\circ} \mathrm{C}$ for 7 days after the preparation. With the passage of time, the interface between the two phases was analyzed: the first phase was rich in oil, and the second phase, which was turbid and more abundant in the lower part of the tube.

The $\mathrm{pH}$ of the emulsions were measured by $692 \mathrm{pH} / \mathrm{Ion}$ meter (Metrohm, Switzerland) with the accuracy of $0.002 \mathrm{pH}$ units using the combined LL pH glass electrode with temperature sensor Pt1000 (Metrohm, Switzerland), pre-calibrated with standard buffers $(1.68,4.01,6.86,9.18$ and 12.45) at $25^{\circ} \mathrm{C}$.

All weighing operations were carried out on a balance IKEA (IKEA GmbH, Germany) with accuracy $0.01 \mathrm{~g}$.

\section{Data Treatment}

Stability of emulsions in percent of emulsion intact were calculated from experimental data according expression [36]:

$$
\text { Stability }(\%)=\frac{V}{V_{0}} 100 \%,
$$

where $\mathrm{V}$ is a volume of intact emulsion, $\mathrm{V}_{0}$ is a volume of emulsion's sample.

Creaming index of emulsion as the percent ratio of the height of serum phase (bottom layer) HSP and to the height of total emulsion HTE were calculated by expression: 


$$
\mathrm{CI}(\%)=\frac{\mathrm{HSP}}{\mathrm{HTE}} 100 \% \text {. }
$$

The obtained experimental data on the shear stress $\tau$ versus the shear rate $\gamma$ were used to calculate the effective dynamic viscosity $\eta$ of the emulsions at ambient temperature according to the expression (3):

$$
\eta=\tau / \gamma
$$

All calculations were performed automatically in the software ORCADA ${ }^{\text {TM }}$ Model 900 software (OFI Testing Equipment,, Inc., USA).

\section{Statistic analysis}

For the statistical analysis were used a one-factor analysis (ANOVA) for a series of parallel measurements $(\mathrm{n}=3$ ) with the statistical software package Minitab ver. 18.1 (Minitab Inc., USA). Value of $\mathrm{p}<0.05$ was considered statistically significant. The Tukey-Kramer honestly significant test was used to determine significant difference between means. All data were expressed as the $X \pm \Delta X$ with $X$ as average value and $\Delta \mathrm{X}$ as standard deviation.

The approximation of the experimental data was evaluated by two parameters: the correlation coefficient $\mathrm{R}^{2}$ and standard error $\sigma_{e s t}$.

\section{Results and Discussion}

Emulsion curves of flow and model fitting. As you know, most food emulsions are nonNewtonian liquids that exhibit thixotropic behavior. Indeed, the obtained rheograms for emulsions demonstrate the typical behavior of fluids with a non-Newtonian flow in the range of the studied shear rates. In addition, there is a characteristic hysteresis for the flow curves depending on the direction of change in the shear stress. Thixotropy is an integral property of a structured dispersed system, in which particles of a dispersed phase form aggregates, most commonly flocculates. Equations of flow, according to literature data, characterize the equilibrium state of flow in the presence of some equilibrium structure. Rheology studies of highly flocculated gels are difficult due to poor reproducibility of sample preparation, sensitivity to shear history, and preparation conditions [37]. However, weak or reversible flocculation allows the destruction and re-formation of aggregates with the achievement of a metastable thermodynamic state. Taking this fact into account, in further experiments to obtain a flow curve close to the equilibrium state, sequential measurements were carried out $(\uparrow \downarrow \uparrow)$, where $\uparrow-$ means viscosity measuring with increasing shear rate, and $\downarrow-$ conversely. The curves presented in the following discussion refer to $(\uparrow)$ measurements. Taking into account the comments made, the flow curves of CMC solution $(0.75 \% \mathrm{w} / \mathrm{w})$ and CMC+WPI with concentration CMC $(0.75 \% \mathrm{w} / \mathrm{w})$ and protein $(2 \% \mathrm{w} / \mathrm{w})$ and the studied emulsions are shown in Fig. 2. In addition, this figure has shown a curve for a dilute emulsion EMP with a viscosity $1.9 \mathrm{mPa} \cdot \mathrm{s}$. This diluted emulsion was used in the experiment to determine the size distribution and zeta-potential by the DSL method. The curve is linear $\left(\mathrm{R}^{2}=0.9955\right)$ with practically zero intercept, which confirms the Newtonian type of flow with a constant viscosity $(1.9 \mathrm{mPa} \cdot \mathrm{s})$. The rest of the curves, including the CMC and mixed CMC + WPI solutions, have a non-linear dependence shear stress versus shear rate (Fig. 1).

To approximate the obtained experimental data, we considered the most commonly used (for food materials) to study the relationship between the shear stress and shear rate of the model [21]: powerlaw (4), Herschel-Bulkley (5) and Casson (6):

$$
\begin{gathered}
\tau=K \gamma^{n} \\
\tau=\tau_{0}+K \gamma^{n}
\end{gathered}
$$

where $\tau$ is shear stress $(\mathrm{Pa}), \tau_{0}$ is yield shear stress $(\mathrm{Pa}), \gamma$ is shear rate $\left(\mathrm{s}^{-1}\right), \mathrm{K}$ is consistency coefficient $(\mathrm{Pa} \mathrm{s}), \mathrm{n}$ is flow behavior index (dimensionless),

$$
\tau^{1 / 2}=\tau_{k}^{1 / 2}+\eta_{\infty}^{1 / 2} \gamma^{1 / 2}
$$

where $\tau_{k}$ is the yield stress, $\eta_{\infty}$ is the Casson viscosity, which relates to the high shear rate viscosity. The above models are widely used to describe various food systems. Their disadvantage is the physical unreasonableness of the exponent index $n$. However, in some rheological studies, the constant $\mathrm{n}$ is 
considered as the shear thinning index. This describes the degree to which a material is shear thinning $(\mathrm{n}<1$, pseudoplastic) or shear thickening ( $\mathrm{n}>1$, dilatant). For $\mathrm{n}=1$ we have Newtonian behavior. The above also applies to the uncertainty of the consistency coefficient. Table 3 summarizes the results of the evaluation of parameters of power-law model.

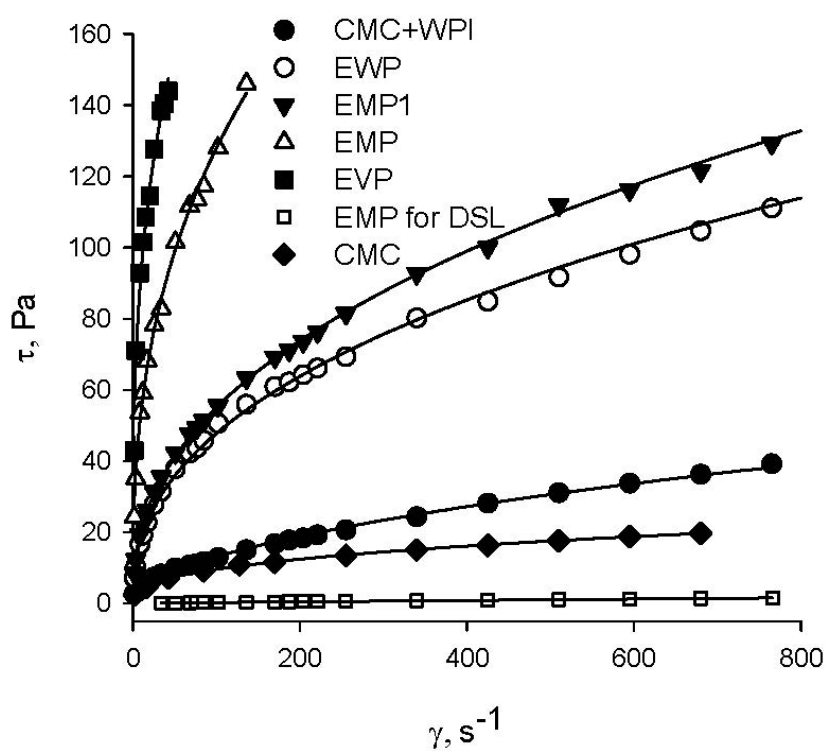

Figure 1. Curves of flow for solution $\mathrm{CMC}$ and $\mathrm{CMC}+\mathrm{WPI}$, and emulsions (dots are experimental data; the lines are the results of approximation by the eq. 4)

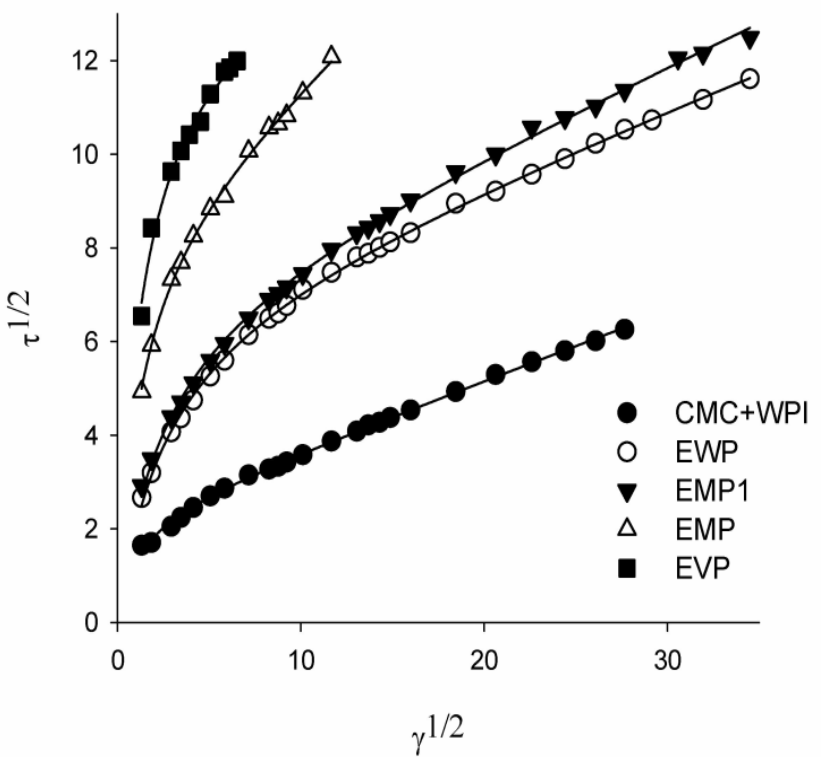

Figure 2. Curves of flow as $\tau^{1 / 2}$ versus $\gamma^{1 / 2}$ plot (dots are experimental data; the lines are the results of approximation by the eq. 7)

Table 3. Coefficients the flow equation of the power-law and Herschel-Bulkley models

\begin{tabular}{cccccc}
\hline Sample & $\tau_{0}, \mathrm{~Pa}$ & $\mathrm{~K}, \mathrm{~Pa} \mathrm{~s}$ & $\mathrm{n}$ & $\mathrm{R}^{2}$ & $\sigma_{\text {est }}$ \\
\hline EWP & $0.2 \pm 1.4$ & \multicolumn{7}{c}{ Herschel-Bulkley model } \\
EMP1 & $-0.9 \pm 0.5$ & $0.42 \pm 0.01$ & 0.9987 & 1.6 \\
EMP & -8 & $8.8 \pm 0.5$ & $0.42 \pm 0.01$ & 0.9994 & 1.2 \\
EVP & -295 & $29 \pm 6$ & $0.34 \pm 0.03$ & 0.9969 & 2.4 \\
\hline \multicolumn{7}{c}{$44 \pm 2$} & $0.291 \pm 0.011$ & 0.9912 & 3.4 \\
EWP & \multicolumn{7}{c}{ Power-law model } \\
EMP1 & $7.0 \pm 0.2$ & $0.418 \pm 0.004$ & 0.9987 & 1.6 \\
EMP & $7.8 \pm 0.1$ & $0.424 \pm 0.003$ & 0.9994 & 1.2 \\
EVP & \multicolumn{7}{c}{$0.360 \pm 0.008$} & 0.9969 & 2.2 \\
\hline
\end{tabular}

The analysis of the results (Table 3), carried out on the basis of a comparison of the correlation coefficient and the standard deviation of the experimental data from the data that were calculated using the nonlinear regression equation showed:

1) the best approximating ability, according to the adopted criteria, is possessed by the power-law model (4), which in the further analysis of the curves of the dependence of the shear stress on the shear rate was taken as the basis (Fig. 1);

2) when calculating by the Herschel-Bulkley model, statistically insignificant or negative values of yield shear stress yield shear stress $\tau_{0}$, were obtained for all emulsions, which has no physical meaning;

3) curves in the coordinates $\tau^{1 / 2}-\gamma^{1 / 2}$ of Casson model had a pronounced nonlinear character (Fig. 2), which indicated that there was no need for calculations using a straight-line dependence (eq. 6);

4) the calculated values of $\mathrm{n}$ less than 1 for all systems indicate their typical pseudoplastic flow (taking into account $\tau_{0}=0$ according to (eq. 4 ); 
5) an increase in $\mathrm{K}$ and a decrease in $\mathrm{n}$ in the series of emulsions EWP $<$ EMP $<$ EVP testifies in favor of an increase in the structuredness of the resulting emulsions.

The obtained $\mathrm{K}$ value for the EWP is in good agreement with the similar value obtained for the emulsion with whey protein, taking into account the higher viscosity of rapeseed oil [24].

Earlier, in [35] to describe the behavior of aqueous solutions of food gelling agents for the analysis of the obtained curves of flow, we used the generalized flow equation of the Casson rheological model [38]. Initially, this model was developed for polymer melts [39], but it is suitable for describing dispersed systems, including emulsions and suspensions [40,41].

The rheological behavior of the system within the framework of the discussed model is explained by a change in the structure, which is understood as a certain arrangement in space of individual or interconnected particles, in our case, emulsion drops. The structure is characterized by the size distribution of particle aggregates, the shape of the particles or aggregates, the internal structure of the aggregates and their orientation in space. This model is a generalization and extension to real systems of the classical microrheological model Casson [42] with an additional interpretation of the coefficients of this model based on the kinetic equations of destruction - recovery of structural aggregates of the Kross model [43]. The proposed mechanism of viscous flow is associated with the dissipation of the energy of this flow when flowing around a set of aggregates and individual particles under the condition of their hydrodynamic interaction, the possible destruction of aggregates due to breaking hydrodynamic forces and unification during collisions of particles and aggregates [38]. The generalized flow equation for this approach is represented by the expression (7):

$$
\tau^{1 / 2}=\frac{\tau_{c}^{1 / 2} \gamma^{1 / 2}}{\chi+\gamma^{1 / 2}}+\eta_{c}^{1 / 2} \gamma^{1 / 2}
$$

where values $\tau_{c}^{1 / 2}, \chi, \eta_{c}^{1 / 2}$ - are integral characteristics of a structured system, in our case, emulsions. Their values are obtained by approximating the experimental data of flow curves in a wide range of shear rates in the region where an increase in shear stress is observed. Unlike expressions (4)-(6), these parameters have a physical meaning based on the kinetic model of destruction-recovery of structural aggregates of the system [44]. This meaning becomes clear if we take into account that the first term of eq. (7) corresponds to energy dissipation in the flow around particle aggregates, and the second - to energy losses during the movement of individual particles. The coefficient $\tau_{c}^{1 / 2}$ characterizes the degree of aggregation of the system and takes on the meaning of the limiting dynamic shear stress only under the condition $\chi \rightarrow 0$. The coefficient $\chi$ indicates a tendency towards the formation of an infinitely large aggregate of particles and is associated with the looseness or compactness of an individual aggregate of particles. It determines the plastic or pseudoplastic behavior of a structured system. These coefficients are related to the parameters of the kinetic equation, which considers the motion of particles in a viscous medium, which aggregate upon mutual collision, and are separated under the influence of thermal motion and hydrodynamic tensile forces. Casson viscosity coefficient $\eta_{c}^{1 / 2}$ is equal to the viscosity of the system with complete destruction of the original aggregates, i.e., it is associated with the flow of a viscous dispersion medium around individual particles. From this it follows that the parameter $\eta_{c}$ can be considered as the total viscosity of the system with the complete destruction of the associates of the dispersed system [41].

In [41] the authors emphasized that the calculation of the coefficients of the approximating expression for curves of flow largely depends on the choice of the shear rate range. This is especially true when considering the range of high shear rates. The authors of the aforementioned work proposed a choice of different values of the coefficients of the rheological equation in the field of high and low speeds. To analyze the influence of the choice of the shear rate range on the values of the coefficients eq. (7), a calculation was carried out for emulsions EWP and EMP1, for which experimental data were obtained in the maximum range 1-1191 s $\mathrm{s}^{-1}$ (Table 4, Fig. 2). The same data was processed in a narrower shear rate range $1-51 \mathrm{~s}^{-1}$. Comparison of the results obtained indicates their significant difference. This is noted for all considered coefficients eq. 7. It should be noted that the values of the coefficient $\chi$ in the region of low velocities are always significantly less than in the region of high shear rates. This indicates a tendency for the formation of a continuous framework (network) in the case of low flow rates and a transition to the plastic type of flow. The results obtained confirm the conclusions of the calculations [41]. 
Table 4. Coefficients the generalized flow equation of the Casson rheological model

\begin{tabular}{|c|c|c|c|c|c|c|c|}
\hline \multirow[b]{2}{*}{ Sample } & \multicolumn{2}{|c|}{ Calculation parameters } & \multirow[b]{2}{*}{$\tau_{c}^{1 / 2}$} & \multirow[b]{2}{*}{$\chi$} & \multirow[b]{2}{*}{$\eta_{c}^{1 / 2}$} & \multirow[b]{2}{*}{$\mathrm{R}^{2}$} & \multirow[b]{2}{*}{$\sigma_{e s t}$} \\
\hline & $\begin{array}{l}\text { Shear rate } \\
\text { range, } \mathrm{s}^{-1}\end{array}$ & $\begin{array}{c}\text { Points } \\
\text { number }\end{array}$ & & & & & \\
\hline \multicolumn{8}{|c|}{ Solution (aqueous phase of emulsion EWP) } \\
\hline \multirow[t]{2}{*}{$\mathrm{CMC}$} & $1-51$ & 6 & $1.89 \pm 0.18$ & $0.53 \pm 0.20$ & $0.13 \pm 0.02$ & 0.9953 & 0.059 \\
\hline & $1-680$ & 13 & $2.59 \pm 0.12$ & $1.24 \pm 0.19$ & $0.079 \pm 0.005$ & 0.9956 & 0.069 \\
\hline \multirow[t]{2}{*}{$\mathrm{CMC}+\mathrm{WPI}$} & $1-51$ & 8 & $1.43 \pm 0.18$ & $0.17 \pm 0.19$ & $0.25 \pm 0.02$ & 0.9928 & 0.054 \\
\hline & $1-680$ & 23 & $2.31 \pm 0.07$ & $1.00 \pm 0.11$ & $0.147 \pm 0.003$ & 0.9984 & 0.054 \\
\hline \multicolumn{8}{|c|}{ Emulsion } \\
\hline \multirow[t]{2}{*}{ EWP } & $1-51$ & 8 & $4.55 \pm 0.20$ & $1.37 \pm 0.10$ & $0.33 \pm 0.02$ & 0.9997 & 0.023 \\
\hline & $1-1191$ & 27 & $6.94 \pm 0.10$ & $2.63 \pm 0.10$ & $0.151 \pm 0.005$ & 0.9994 & 0.063 \\
\hline \multirow[t]{2}{*}{ EMP1 } & $1-51$ & 8 & $5.04 \pm 0.11$ & $1.33 \pm 0.05$ & $0.32 \pm 0.01$ & 0.9999 & 0.014 \\
\hline & $1-1191$ & 27 & $7.06 \pm 0.14$ & $2.40 \pm 0.13$ & $0.182 \pm 0.005$ & 0.9989 & 0.094 \\
\hline EMP & $1-51$ & 8 & $9.13 \pm 0.91$ & $1.31 \pm 0.23$ & $0.31 \pm 0.09$ & 0.9970 & 0.111 \\
\hline EVP & $1-42$ & 10 & $13.0 \pm 1.8$ & $1.26 \pm 0.31$ & $0.17 \pm 0.18$ & 0.9886 & 0.209 \\
\hline
\end{tabular}

Taking into account the remarks made, in further analysis for a correct comparison of rheological data, calculations for eq. (7) were carried out for all systems in the same range of shear rate, limited by values $1-51 \mathrm{~s}^{-1}$. The exception was the EVP emulsion, for which the entire experimental data range was used (less than that used in calculations for other samples).

Data analysis of Table 4, can be summarized:

1) the generalized flow equation of the Casson rheological model has the best approximating ability in relation to the power model according to the criterion under consideration $\sigma_{e s t}$;

2) coefficient $\tau_{c}^{1 / 2}$, characterizes the degree of aggregation of the system, increases in the series of emulsions EWP-EMP-EVP and indicates an increase in structuredness in this series;

3 ) it is obvious that the formed EWP emulsions are more structured in comparison with the dispersion medium (aqueous phase of emulsion EWP), the coefficient of the degree of aggregation of which is 3 times higher;

4) obtaining values $\chi>0$, confirms the conclusion about pseudoplastic behavior of emulsions obtained on the basis of the power model;

5) in the series of emulsions EWP-EMP-EVP pseudoplastic behavior, based on a statistical assessment, practically does not change;

6) $\mathrm{CMC}$ solution has a higher degree of particle aggregation than $\mathrm{CMC}$ solution with added WPI protein;

7) sample CMC + WPI is a non-linear plastic fluid $(\chi \rightarrow 0)$, at least to a greater extent than the CMC solution, which can be classified as pseudoplastic fluids;

8) the total viscosity of the system with the complete destruction of any associates is practically the same for all emulsions, as evidenced by the parameter $\eta_{c}$, the exception is the EVP emulsion, but in this case it is observed as a result of the choice of points for approximation and a greater statistical estimate of the obtained value.

When commenting on the results, it should be noted that the introduction of protein into the CMC solution leads to a system with a more plastic flow, which is confirmed by a decrease in the coefficient $\chi$. At the same time, the degree of aggregation of particles in the system decreases. These facts indicate the presence of a more compact and durable structure.

Apparent viscosity. As seen from Fig. 3 and 4, the viscosity of all studied systems depends on the shear rate or stress, which is typical for non-Newtonian fluids. As the shear rate increases, the viscosity decreases. The viscosity increases with the range of emulsions EWP EMP $1<$ EMP $<$ EVP.

The value of the viscosity of the EWP emulsion significantly, almost by an order of magnitude, prevails the same indicator for the dispersed medium CMC + WPI (these data are not shown in the figures). This indicates that the main contribution to the viscosity of the emulsion is made by the effect 
associated with the colloidal interaction of the components of the emulsion. And the viscosity of the solution of $0.75 \% \mathrm{CMC}$ as a thickener increases the viscosity of the emulsion, according to approximate calculations, up to $30 \%$.

There are two things to note (Fig. 3). The first of them shows that the EMP emulsion, created by homogenization at a rotation speed of $24000 \mathrm{rpm}$, has a higher viscosity at a certain shear rate value than the same EMP1 emulsion, but obtained at a speed $14000 \mathrm{rpm}$. Another fact is related to the fact that, as can be seen, the viscosities of the EWP and EMP1 emulsions are equal and have the same rheological behavior during shear. Based on this, we can assume a hypothesis about their identity regarding stability over time. It is based on a study [24], in which an emulsion based on WPI prepared by the same method and differing only in the nature of the rapeseed oil had a high VD stability (Table 1). This suggests similar results for the EWP emulsion. Taking into account the ratio of the viscosities of the studied emulsions, this assumption can be extended to the rest of the emulsions. So far, this is a hypothesis requiring experimental confirmation in future research.

Homogenization at $24000 \mathrm{rpm}$ was also used to obtain an emulsion on rapeseed oil with WPI. In our case, simpler and cheaper equipment was sufficient to obtain an emulsion with similar rheological properties. This is an important economic factor in the practical implementation in production. Using the same homogenization conditions $(24000 \mathrm{rpm})$ in this study, an emulsion with better rheological properties is obtained, and, presumably, more stable.

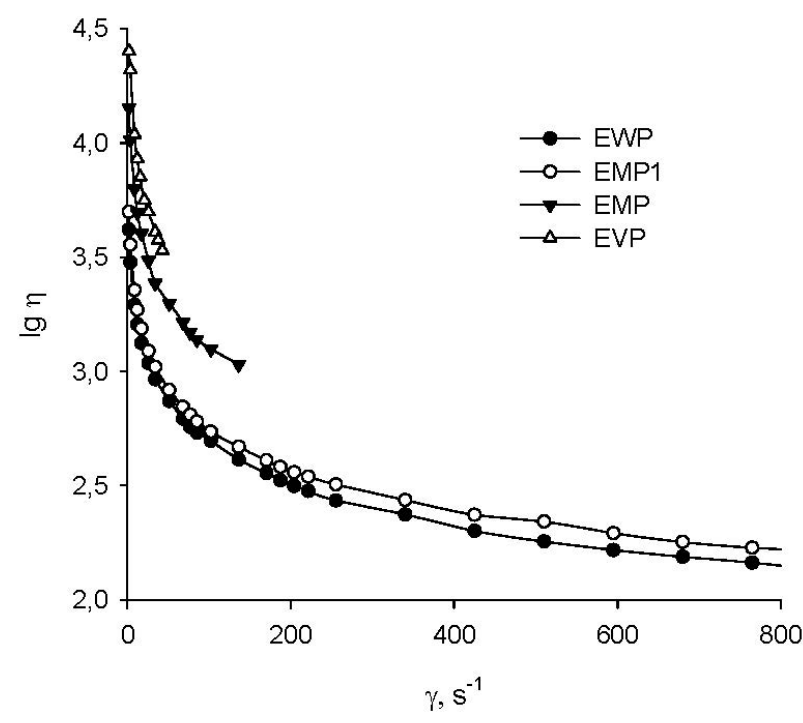

Figure 3. Logarithmic of viscosity $(\mathrm{Pa} \cdot \mathrm{s})$ versus shear rate for emulsions

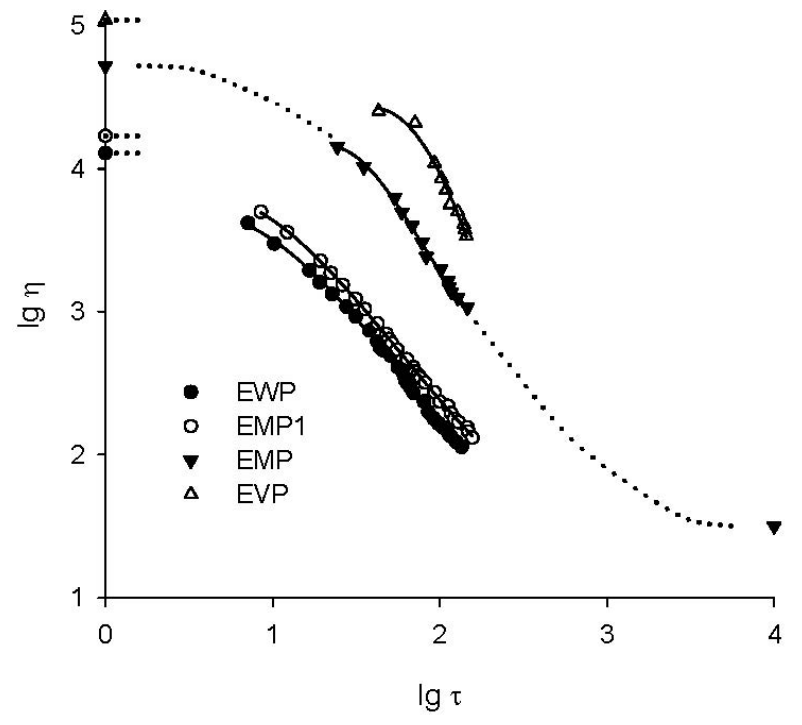

Figure 4. Viscosity $(\mathrm{Pa} \cdot \mathrm{s})$ curves on shear stress $(\mathrm{Pa})$ in double logarithmic coordinates

(dotted lines shows schematic full viscosity curve from eq. (10); dots at $\lg \tau=4$ and on ordinate axis shows $\left(\lg \eta_{\infty}\right)$ and zero-shear viscosity plateau $\left(\lg \eta_{0}\right)$ for EMP emulsions, respectively)

The most common type of non-Newtonian behavior is shear thinning or pseudoplastic flow, where the fluid viscosity decreases with increasing shear stress (Fig. 4). Shear thinning is the result of microstructure restructuring occurring in the plane of applied shear. Typical such flow curves for shear thinning fluids with a zero shear viscosity $\eta_{0}$ (viscosity shows a plateau as the shear rate approaches zero) and an viscosity of system viscosity with complete destruction of associates $\eta_{\infty}$ (identical in meaning to the value $\eta_{\mathrm{c}}$ in eq. (7)). Both values characterize a structured and completely destroyed (aggregated structures can be broken down) emulsion with Newtonian behavior at very low and very high shear rates. In this study, only the "shear thinning" area was achieved. In double logarithmic coordinates $\lg \eta-\lg \gamma$ the specified area for all emulsions looks like a linear one (the graph is not presented in the article).

At low shear rates, dispersed systems with pseudoplastic behavior tend to preserve an indestructible structure as a result of the action of two factors: the interaction of particles and the effects of Brownian motion. This structure is characterized by a constant viscosity value, $\eta_{0}$, termed the zero-shear viscos- 
ity or zero-shear viscosity plateau. The generalized flow equation (7) of the Casson rheological model with considering eq. (3), can be converted to form:

$$
\eta^{1 / 2}=\frac{\tau_{c}^{1 / 2}}{\chi+\gamma^{1 / 2}}+\eta_{c}^{1 / 2}
$$

Value $\eta_{0} \eta_{0}$ is viscosity of emulsion at the shear rate approaches zero:

$$
\eta_{0}^{1 / 2}=\frac{\tau_{c}^{1 / 2}}{\chi}+\eta_{c}^{1 / 2} \text { at } \gamma \rightarrow 0
$$

on the other hand:

$$
\eta_{\infty}^{1 / 2} \cong \eta_{c}^{1 / 2} \text { at } \gamma \rightarrow \infty
$$

Calculated by eq. (9) the values $\eta_{0}$ are schematically shown in Fig. 4 as dots on the ordinate with dashed lines perpendicular to the axis, denoting a plateau on the rheological curve with a constant viscosity. For the studied emulsions, the values are 13.3, 16.9, 53.0 и $110 \mathrm{~Pa} \cdot \mathrm{s}$, increasing in the series $\mathrm{EWP}<\mathrm{EMP} 1<\mathrm{EMP}<\mathrm{EVP}$.

If the coefficient $\chi$ is equal to zero, which can be roughly attributed to the WPI + CMC system, then the dimensions of the unit increase indefinitely at $\gamma \rightarrow 0$. In this case, a nonlinear plastic flow is observed with value $\tau_{\mathrm{c}}$ as yield shear stress. This means a tendency to form a continuous framework (network) at zero shear rate [45]. For the studied emulsions $\chi$ is greater than zero (Table 4) and pseudoplastic flow is observed. This behavior is characterized by the size of the aggregates of the system with finite dimensions at an infinitely low shear rate. The flow of these units corresponds to the viscosity of the system $\eta_{0}$. This characteristic for dispersed systems is in a good correlation with the rate of creaming or sedimentation and $\eta_{0}$ may be used to assess the flocculation of the dispersion on storage [46]. As a rule, its increase is observed with increased flocculation of the system.

With an increase in the value of $\gamma$ the difference in the values of the viscosities of the emulsions almost disappears (comparison of the values $\eta_{\mathrm{c}}$ in Table 4), which is due to the fact that at a significant bias voltage, the structure of the emulsion is completely destroyed and ratio (10) is satisfied. From Table 4 it can be seen that the calculation of this value depends on the data range. But from an example of calculation for emulsions EWP and EMP1, it can be assumed that for all studied emulsions, when choosing the same and wide range of values $\gamma$ the calculated value $\eta_{c}^{1 / 2}$ will be in the range of $0.15-0.17$ for all emulsions, which gives a value of $\eta_{\infty}$ in the range $0.02-0.03 \mathrm{mPa} \cdot \mathrm{s}$. Fig. 4 schematically shows, as an example, the full viscosity curve for EMP taking into account the calculated values $\eta_{0}$ and $\eta_{\infty}$.

Size distribution of particles. The parameters that characterize the change in the structure of the emulsion due to a certain arrangement in space of individual or interconnected particles were obtained when discussing the data of rheological studies within the framework of the structural approach. This arrangement is characterized by the size distribution of particle aggregates, the shape of particles or aggregates and the internal structure of the aggregates. To explain the data of the rheological experiment, an DSL experiment was carried out to study the microstructure of the obtained emulsions.

The DLS method is used to study the stability of suspensions or emulsions and to evaluate the properties of the dispersed phase, such as particle size and volume fraction [47]. Moreover, the zeta potential of emulsion particles determined by this method can be used as a formulation optimization tool to achieve the desired colloid stability and size distribution. The researched emulsions had a multimodal distribution with tree peaks by volume (Fig. 5), with the majority of droplets having diameters which are given in Table 5.

The first peak on all three histograms, having particle size classes in the range of 100-200 nm, is represented by aggregated molecules of the emulsifier and thickening agent in a dispersion medium that are not adsorbed on the surface of droplets of the fat phase. The presence of such particles in systems is clearly shown on the histograms size distributions by number (Fig. 6). As seen from Fig. 6, the number of non-adsorbed molecules significantly exceeds the number of fat droplets, but due to their small size, their contribution to the volumetric distribution does not exceed $12-13 \%$. When they are introduced into an aqueous dispersion medium, a sufficiently dilute suspension is formed, which coexists in the aqueous phase of the emulsion with the rest of the system. 
Table 5. Zeta potential and average size of particles according data of DLS distribution for emulsions

\begin{tabular}{|c|c|c|c|c|c|c|}
\hline \multirow{2}{*}{ Sample } & \multirow{2}{*}{$\begin{array}{c}\xi- \\
\text { potential, } \\
\mathrm{mV}\end{array}$} & \multirow{2}{*}{$\begin{array}{c}\text { Z-average } \\
\text { diameter, } \\
\mu \mathrm{m}\end{array}$} & \multirow{2}{*}{$\begin{array}{l}\text { Polydispersity } \\
\text { index }\end{array}$} & \multicolumn{3}{|c|}{ Peaks (mean), $\mu \mathrm{m}$} \\
\hline & & & & Molecules peak & Drops peak & Flocs peak \\
\hline EWP & $-61 \pm 1$ & $1.7 \pm 0.1$ & 0.547 & $0.14 \pm 0.02(12 \%)$ & $1.3 \pm 0.1(67 \%)$ & $5.2(21 \%)$ \\
\hline EMP & $-73 \pm 2$ & $3.2 \pm 0.3$ & 0.508 & $0.15 \pm 0.02(13 \%)$ & $1.1 \pm 0.3(72 \%)$ & $5.3(15 \%)$ \\
\hline EVP & $-101 \pm 2$ & $4.1 \pm 0.3$ & 0.620 & $0.09 \pm 0.02$ (n.a.) & $1.0 \pm 0.3$ (n.a.) & $>10$ \\
\hline
\end{tabular}
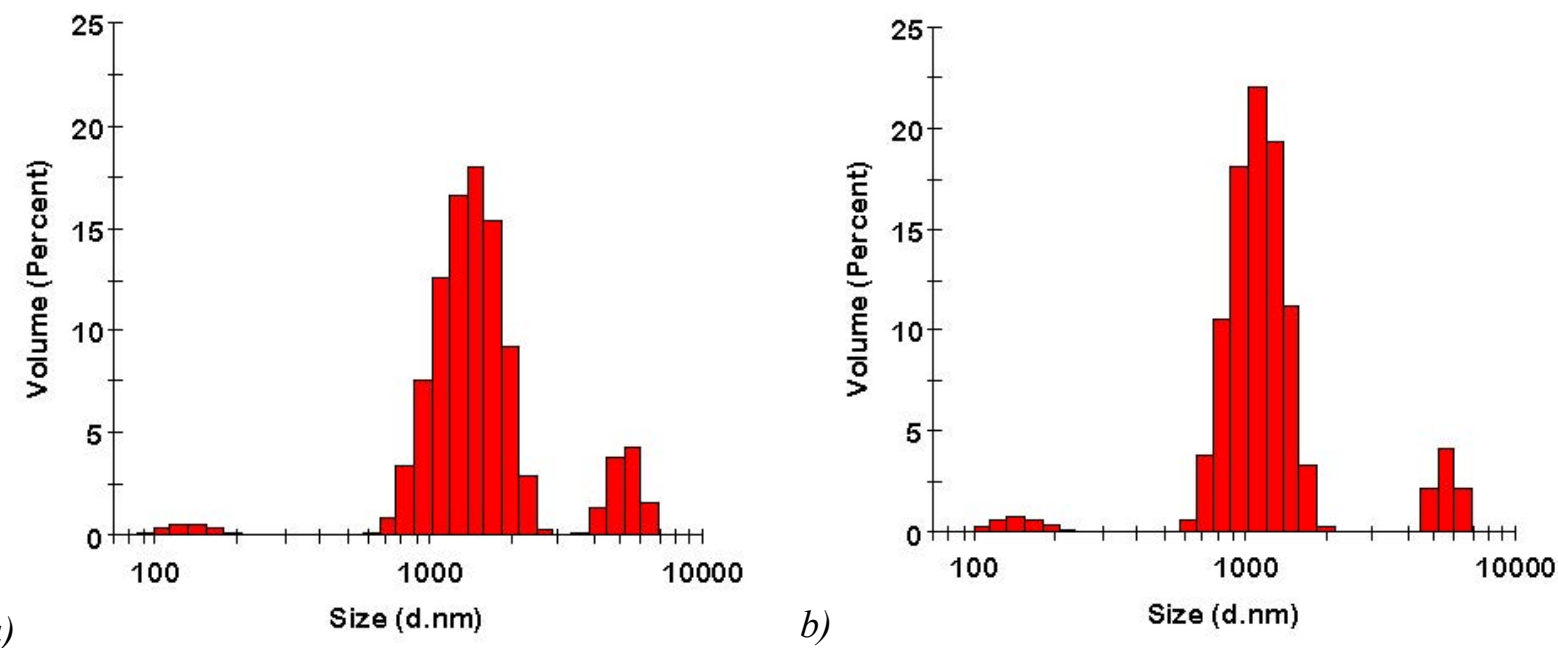

Figure 5. Measured particle size distributions by volume of EWP $(a)$ and EMP $(b)$ emulsions
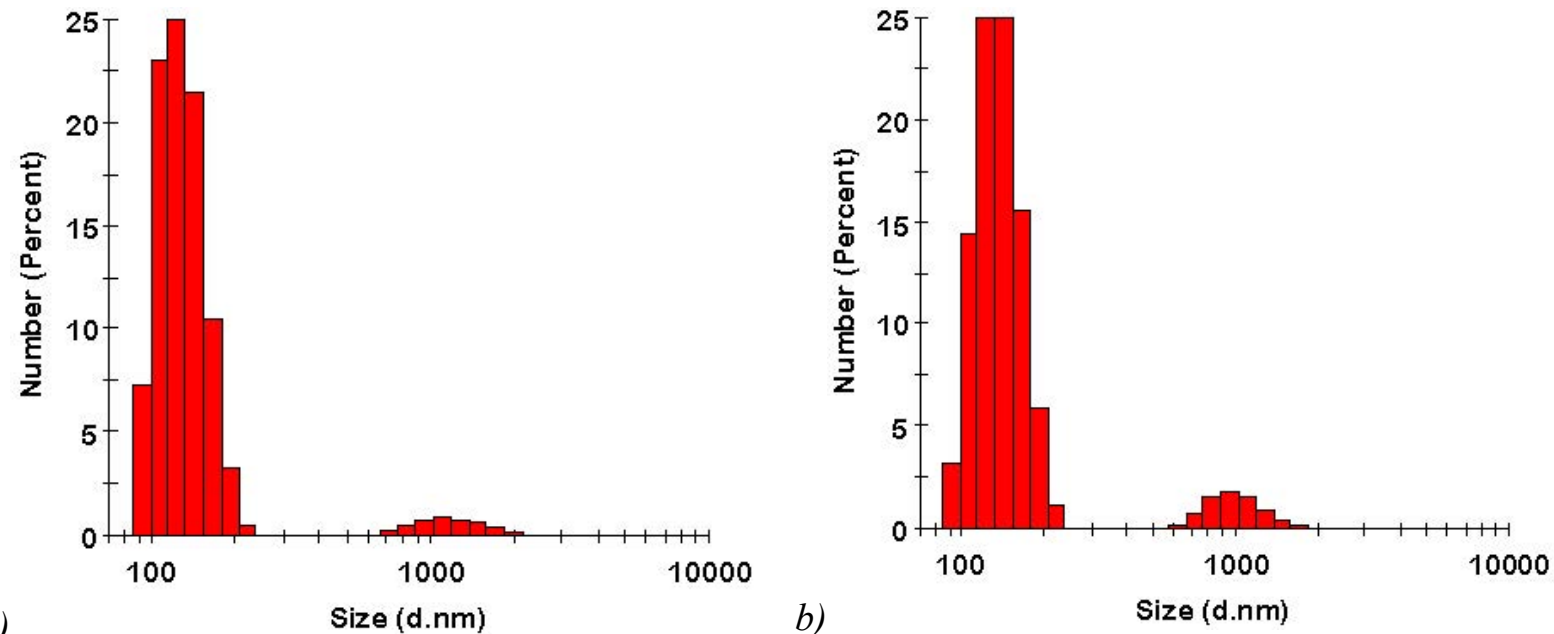

Figure 6. Measured particle size distributions by number of EWP $(a)$ and EMP $(b)$ emulsions

The remaining two peaks on the histograms should be attributed to a relatively broad bimodal distribution of emulsion droplets. This bimodal distribution is an integral part of numerous edible emulsions. Its presence is explained by the processes of droplet flocculation or coalescence in emulsions [19]. Specified structural elements of the emulsion may have non-spherical shapes, e.g. flocculated droplets with open packing. At the same time, it should be noted that this method considers the diffraction of light by spherical particles. The mathematical model of the theory used in the calculations assumes the presence of particles with isolated homogeneous spheres and well-defined optical properties. Flocculated droplets, on the other hand, form rather loose, non-spherical, and heterogeneous structures that have poorly defined optical properties. The floc-like emulsion droplet size distributions determined by laser diffraction should be considered as approximate. And in some cases, as with EVP emulsion, the sizes of such particles exceed the limit of the method and cause the problem of the impossibility of obtaining quantitative indicators. 
The formation of floc-like emulsion in our study, as noted above, is evidenced by the presence of hysteresis in the shear stress versus shear rate curves. This behavior is typical for dispersed systems with weak flocculation [46]. Thus, the second and third peaks in the histograms (Fig. 5) should be attributed to the distribution of emulsion drops and flocculated droplets, accordingly.

As can be seen from Table 5, non-flocculated emulsion droplets make up about $70 \%$ of the sample volume. The size of such droplets decreases in the series of emulsions EVP $<$ EMP $<$ EMP $1<$ EWP. While due to flocculated droplets in the same series, the opposite trend is observed and an increase in Z-average diameter and PI.

Comparison of rheological data and DSL data allows us to conclude that the viscosity of emulsions at a certain value of the shear stress is higher for emulsions with a larger average size of fat droplets. This tendency is typical for flocculated emulsions. [19]. The coefficient $\tau_{c}^{1 / 2}$ calculated using the generalized flow equation (7) of the Casson rheological model, characterizes the degree of aggregation of the system and correlates well with the value Z-average diameter (Fig. 7).

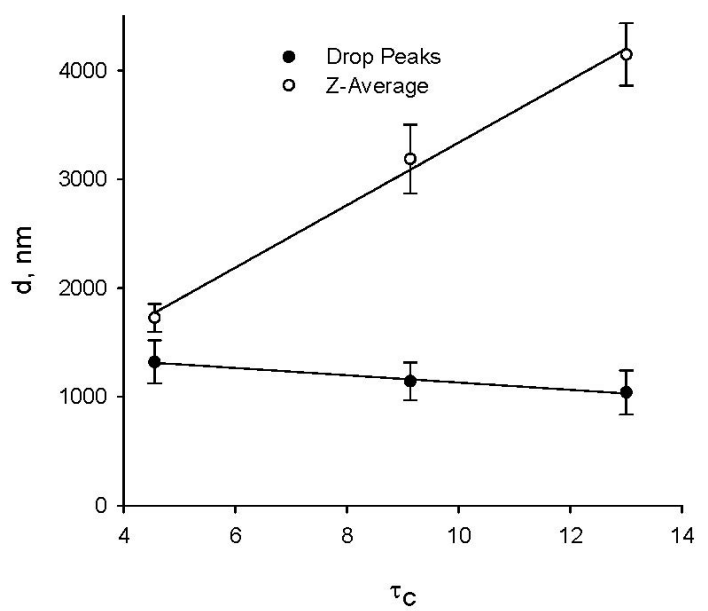

Figure 7. Correlation between different diameters of emulsion droplets and the aggregation coefficient $\tau_{\mathrm{c}}$

In [41] based on calculations by the generalized flow equation of the Casson for model emulsions $(\mathrm{o} / \mathrm{w})$, a result was obtained, according to which, at the same volumetric oil concentration, an increase in the droplet diameter leads to a decrease in $\tau_{c}^{1 / 2}$ и $\eta_{c}^{1 / 2}$. A similar result was noted for suspensions [38]. However, these studies used systems with a rather narrow monomodal particle size distribution. In our case, such dependence is observed if we consider the dependence of the value $\tau_{c}^{1 / 2}$ on the size of non-flocculated drops (Fig. 7). But this value can hardly be regarded as a characteristic of the emulsion as a whole. This option is possible if the rheological behavior of the emulsion without and with floccules is identical, which is far from obvious and requires experimental confirmation. In our study, we should state the fact that the presence of $20 \%$ in the volume distribution of droplets aggregated into floccules leads to a different dependence, if we consider the value of the Z-average diameter as a characteristic of the particle size distribution in emulsions.

Zeta-potential. $\xi$-potential is a measure of electrostatic interaction (repulsion or attraction) between particles, and its change carries information about the state of the interface of coexisting phases. Such information is very important and directly characterizes the factors influencing the stability of dispersed systems. From a practical point of view, the measurement of zeta potential allows for a deeper understanding and better control of the mechanisms of dispersion, aggregation or flocculation, and can be used to improve the properties of dispersed systems in the form of emulsions and suspensions during the development and production stages.

As can be seen from Table 5, negative values were obtained for all emulsions $\xi$-potential. The distribution of the number of particles from the zeta potential is characterized by a peak with a rather wide shape with a range of values from -20 to $-150 \mathrm{mV}$. This fact is not surprising, considering that commercial protein products with a predominant protein content, but with the presence of a certain amount of additional ingredients, were used as emulsifiers. In the case of SMP and VPI, it is also a mixture of proteins of different nature. Therefore, if for EVP a wide but single peak was obtained, then 
for EWP and EMP the distributions are more complex with several local peaks (Fig. 5 and 6). It is impossible to take into account the influence of all particles in a real system. However, by comparing the nature of the curve, the parameters of the peaks and the signs of the charge, one can draw up a certain qualitative picture and interpret the parameters as factors of the stability of emulsions.

A significantly predominant number of particles (more than 90\%) of the system, regardless of the form of distribution, have a zeta potential value much less than the threshold value $-30 \mathrm{mV}$. From the point of view of the classical DLVO theory, this fact and the sign of the potential indicates the existence of strong repulsive force as factor for the stability of emulsions [19]. The sign of the potential is due to the phenomenon of adsorption of molecules of negatively charged particles on the surface of fat droplets. The formation of such particles in the studied emulsions is due to protein molecules. Protein as a polyelectrolyte forms negatively charged particles when the $\mathrm{pH}$ value of the medium exceeds the value of the isoelectric point of the protein. According to the literature, for WPI this is a value of about 4.6 , and at $\mathrm{pH}=7$ of the dispersion medium of emulsions, the zeta potential reaches $-24.3 \mathrm{mV}$ [48]. The authors of [49] give zeta potential of skim milk, evaluated over a wide $\mathrm{pH}$ range, and values reported in literature for various milk proteins. Isoelectric points for SMP proteins are within the $\mathrm{pH}$ range of 4-5, and for skimmed milk about 4.6. With a $\mathrm{pH}$ value of the dispersed medium equal to 7 zeta potential of protein and skimmed milk is in the range of $-30 \ldots-40 \mathrm{mV}$. The VPI used in the experiment contains pea protein isolate and rice protein concentrate. Globulins (referred to as legumin, vicilin and convicilin) represent roughly $70 \%$ of pea seed proteins and the glutelins are the major rice storage proteins [50,51]. Globulins can be used as gelling agents. The isoelectric point for WPI is 5.60 [52]. RPC, principally composed of glutelins as globulin-type subunit in form of monomer or polymer, shows a poor solubility with a minimum at $\mathrm{pH} 4.5$ and maximum solubility in water near $\mathrm{pH}=8$, and zeta potential equal to $-13.1 \mathrm{mV}$ [53]. Thus, with the exception of the casein of SMP protein, all used protein emulsifiers have a globular structure. The data presented confirm dissociation for all proteins in a neutral medium with the formation of negatively charged particles with a zeta potential in the range $-20 \ldots-40 \mathrm{mV}$. This is the distribution of particles with a peak in this area observed for the EWP and EMP emulsions. In the EVP emulsion, the presence of particles with a similar zeta potential value, but without a local peak was also observed. If we also take into account the fact of the presence of the first peak in the size distribution histograms (Fig. 6) in the region of $100 \mathrm{~nm}$, then we can conclude that there are non-adsorbed protein molecules in all studied emulsions. However, the CMC polymer molecules may also contribute to this peak. The dissociation of the anionic polysaccharide is accompanied by the formation of negatively charged particles, which can contribute to the distribution of the negative zeta potential in the system.

And finally, a variant of co-adsorption of fat particles is a protein molecule and a polysaccharide, which was used by the authors to create an emulsion using a mixture of whey protein isolate and CMC [24,33,54]. According [55], when proteins and polysaccharides, or polyelectrolytes are mixed, three different scenarios are possible: (i) segregative phase separation, (ii) cosolubility, and (iii) associative phase separation or complex coacervation. The state diagram for a weak anionic polysaccharide with a globular given by the authors, obtained by generalizing numerous literature data, shows that at $\mathrm{pH}=5-7$ and zero ionic strength (absence of electrolytes) there is a possibility of scenario (ii). It means, that solubility of both polymers or lower formation of soluble or intrapolymer complexes (carrying excess net charge). Weaker reversible complexes tend to be formed between anionic polyelectrolytes and proteins carrying nearly zero overall charge (in isoelectric point of protein) or a net negative charge (at pH slightly exceeding the isoelectric point) [32]. In this case, a layer of biopolymer layers is formed at a planar oil - water interface, which represents a mixed layer from simultaneous adsorption in the form of charged complexes. In our study, we used the method of emulsion stabilization at a $\mathrm{pH}$ close to neutral, which should be considered as a significant excess of the protein isoelectric point. Therefore, in emulsions stabilized with a mixture of WP and CMC, the polysaccharide molecules remain unabsorbed on the oil drop. For those non-adsorbing polysaccharides that do not form complexes with proteins, the mechanistic control of emulsion rheology and stability arises from thickening and gelling effects in the continuous aqueous phase, and also the generation of aggregated emulsion structures through depletion flocculation [56]. Authors [57] a study was carried out (o/w) emulsion containing $10-40 \%$ sunflower oil, stabilized by $\beta$-lactoglobulin with $1 \%$ emulsifier. Shown to form depletionflocculated emulsions, by addition of the polysaccharide $\mathrm{CMC}$ to emulsions that were at $\mathrm{pH} 6.7$. 
The indicated literary sources confirm the data obtained in our study on the size distribution of particles and zeta potential. The process of flocculation of emulsion droplets is a destabilizing factor for emulsions, but how critical it is for obtaining the final product can only be confirmed by an experimental study of the stability of emulsions over time.

Stability of emulsions. Conducted according to the standard of Ukraine DSTU 4560: 2006 [36] studies on the stability of emulsions showed the result, according to which the Stability indicator was equal to $100 \%$. The indicated value was obtained for all studied emulsions, regardless of the type of emulsifier used. Similar results were obtained in the study CI. Thus, the results obtained indicate the existence of partial flocculation of the studied emulsions. This process is explained by non-adsorbing of biopolymer CMC due to depletion flocculation. But the speed of the further process of aggregation of systems does not affect the stability of the emulsions during the studied time interval.

These facts testify in favor of the economic criterion in the form of the cost of raw materials for choosing an emulsifier when creating an emulsion-based delivery system. And despite the increased amount of SMP emulsifier in the emulsion formulation, due to the lowest protein content, this particular ingredient should be considered as the main one in further research and technology developments of fortified vitamin $\mathrm{D}$ foods.

\section{Conclusions}

This study focused on the influence of surfactant type on the formation and stability of surfactantbased colloidal dispersions as emulsion-based delivery systems of vitamin $\mathrm{D}$. The objects were $(\mathrm{o} / \mathrm{w})$ emulsions containing $40(\% \mathrm{w} / \mathrm{w})$ sunflower oil, stabilized (as an emulsifier) with a mixture of protein with a content of $2(\% \mathrm{w} / \mathrm{w})$ and carboxymethylcellulose $0.75(\% \mathrm{w} / \mathrm{w})$. The proteins used were commercial products in the form of isolates or concentrates: whey protein, skimmed milk powder and vegan protein. In the course of this work, rheological data for the indicated emulsions were obtained on a rotary viscometer in shear rate range 1-1191 s $\mathrm{s}^{-1}$. All of these systems have typical flow curves for shear thinning fluid with thixotropic behavior. This fact shows that rheological studies can be used to study the state of flocculation of emulsions. Weakly flocculated dispersions usually exhibit thixotropy and the study of the parameters characterizing its change over time can be used as an indicator of the aggregation force of the particles of the system, as well as the type of flocculation.

The obtained experimental flow curves were approximated by power-law, Herschel-Bulkley and Casson equations. Analysis of the calculations showed that the power-law model has the best approximating ability. The values calculated within this model indicate that all emulsions are structured systems with shear thinning or pseudoplastic flow. The value of consistency coefficient increased, and the flow behavior index decreased in the series of emulsions EWP $<$ EMP $<$ EVP, which indicated an increase in the structuredness of the resulting emulsions. To quantitatively confirm this conclusion, calculations were carried out within the framework of the structural approach based on the generalized Casson rheological model. The calculated coefficients $\tau_{c}^{1 / 2}$, characterizing the degree of aggregation of the system increased in the indicated series of emulsions. The obtained values $\chi>0$ confirmed the pseudoplastic behavior. The contributions of the integral characteristics of the associates of macromolecules $\eta_{0}$ and individual particles $\eta_{\infty}$ calculated from the experimental data during their hydrodynamic interaction in the process of viscous flow made it possible to quantitatively characterize the dependence of the change in the effective viscosity on the change in the nature of the emulsifier of emulsions.

For a possible explanation of the obtained data of the rheological experiment, an experiment was carried out to study the microstructure of these emulsions using light scattering techniques. The researched emulsions had a multimodal distribution with tree peaks by volume. The first peak in all three histograms, having particle size classes in the range of 100-200 $\mathrm{nm}$ and a contribution to the volume distribution not exceeding $5 \%$, is represented by aggregated molecules emulsifier and thickening agent that are not adsorbed on the surface of fat phase droplets. The other two peaks belong to bimodal distribution of drops in typical floc-like emulsion. Non-flocculated emulsion droplets make up about $70 \%$ of the sample volume, their size is about $1.0-1.3 \mu \mathrm{m}$ and decreases in the series of emulsions $\mathrm{EWP}<\mathrm{EMP}<\mathrm{EVP}$.

The calculated electrophoretic mobility is converted into zeta potential values. The obtained zeta potential values of emulsions EWP, EMP and EVP have the values $-59.5,-72.3$ and $-101 \mathrm{mV}$, re- 
spectively. From the point of view of the classical DLVO theory, this indicates the existence of strong repulsive force as factor for the stability of emulsions. The sign of the potential and its value indicate the process of adsorption on the surface of the fat phase of weaker reversible complexes, that to be formed between anionic polyelectrolytes and proteins. The presence of flocculated particles is explained by the fact that non-adsorbing polysaccharides that do not form complexes with proteins, capable of generating generation of aggregated emulsion structures through depletion flocculation.

Despite the destabilizing factor in the form of the formation of flocculated particles, we found that all surfactant was capable of forming stable emulsions. Thus, we can conclude that regardless of the choice of the type and nature of the protein emulsifier - animal or plant origin, all studied systems can be considered for use as emulsion-based delivery systems of VD. But, you should pay attention to the fact that the cost of skimmed milk powder, in comparison with food additives containing proteins of various nature in high concentrations, is much less. From an economic point of view, cost is one of the key factors in the development of commercial food technology. Studies have shown the combination of this emulsifier with carboxymethylcellulose gives good results in terms of obtaining stable emulsions with the required rheological characteristics even when using less expensive homogenization equipment.

The resulting emulsions can be used as a basis for the production of vitamin D-fortified foods, in particular for dairy products. However, the full development cycle of such products should include tasks related to the study of the safety of VD in the food matrix and verification of its bioavailability during the digestion process.

\section{Acknowledgements}

Authors thanks Prof. Mchedlov-Petrosyan N.O. for the helpful discussion of the results of the DLS and zeta-potential measurements. O.N.K acknowledge Grant No. 0119U002532 of the Ministry of Education and Science of Ukraine.

\section{References}

1. Meza-Meza M.R., Ruiz-Ballesteros A.I., de la Cruz-Mosso U. Functional effects of vitamin D: From nutrient to immunomodulator. Crit. Rev. Food Sci. Nutr. 2020, 1-21. https://doi.org/10.1080/10408398.2020.1862753.

2. Holick M.F., Chen T.C. Vitamin D deficiency: A worldwide problem with health consequences. Am. J. Clin. Nutr. 2008, 87 (4), 1080S-1086S. https://doi.org/10.1093/ajen/87.4.1080s.

3. Maurya V.K., Bashir K., Aggarwal M. Vitamin D microencapsulation and fortification: Trends and technologies. J. Steroid Biochem. Mol. Biol. 2020, 196, 105489. https://doi.org/10.1016/j.jsbmb.2019.105489.

4. Pankiv V.I., Povorozniuk V.V., Pankiv I.V., Boyko V.I., Glugovska S.V. Vitamin D status in the population of the Western region of Ukraine. Int. J. Endocrinol. 2019, 15 (3), 268-271. https://doi.org/10.22141/2224-0721.15.3.2019.172115.

5. Pannu P.K., Calton E.K., Soares M.J. Calcium and Vitamin D in Obesity and Related Chronic Disease. In Advances in Food and Nutrition Research, Elsevier Inc.: 2016, Vol. 77, pp 57-100. https://doi.org/10.1016/bs.afnr.2015.11.001.

6. Rybchyn M.S., Abboud M., Puglisi D.A., Gordon-Thomson C., Brennan-Speranza T.C., Mason R.S., Fraser D.R. Skeletal Muscle and the Maintenance of Vitamin D Status. Nutrients 2020, 12 (11), 3270. https://doi.org/10.3390/nu12113270.

7. Schmid A., Walther B. Natural Vitamin D Content in Animal Products. Adv. Nutr. 2013, 4 (4), 453-462. https://doi.org/10.3945/an.113.003780.

8. Al-Daghri N.M., Amer O.E., Khattak M.N.K., Sabico S., Ghouse Ahmed Ansari M., Al-Saleh Y., Aljohani N., Alfawaz H., Alokail M.S. Effects of different vitamin D supplementation strategies in reversing metabolic syndrome and its component risk factors in adolescents. J. Steroid Biochem. Mol. Biol. 2019, 191 (November 2018), 105378. https://doi.org/10.1016/j.jsbmb.2019.105378.

9. Vitamin D, 4th Editio., Feldman D., Ed., Academic Press: 2018. https://doi.org/10.1016/C2015-0052921-4.

10. Galanakis C.M. The Food Systems in the Era of the Coronavirus (COVID-19) Pandemic Crisis. Foods 2020, 9 (4), 523. https://doi.org/10.3390/foods9040523. 
11. Pereira M., Dantas Damascena A., Galvão Azevedo L.M., de Almeida Oliveira T., da Mota Santana J. Vitamin D deficiency aggravates COVID-19: systematic review and meta-analysis. Crit. Rev. Food Sci. Nutr. 2020, 0 (0), 1-9. https://doi.org/10.1080/10408398.2020.1841090.

12. Vyas N., Kurian S.J., Bagchi D., Manu M.K., Saravu K., Unnikrishnan M.K., Mukhopadhyay C., Rao M., Miraj S.S. Vitamin D in Prevention and Treatment of COVID-19: Current Perspective and Future Prospects. J. Am. Coll. Nutr. 2020, O (0), 1-14. https://doi.org/10.1080/ 07315724.2020.1806758.

13. Ye K., Tang F., Liao X., Shaw B.A., Deng M., Huang G., Qin Z., Peng X., Xiao H., Chen C., et al. Does Serum Vitamin D Level Affect COVID-19 Infection and Its Severity?-A Case-Control Study. J. Am. Coll. Nutr. 2020, 0 (0), 1-8. https://doi.org/10.1080/07315724.2020.1826005.

14. Silva P.T. da, Fries L.L.M., Menezes C.R. de, Holkem A.T., Schwan C.L., Wigmann É.F., Bastos J. de O., Silva C. de B. da. Microencapsulation: concepts, mechanisms, methods and some applications in food technology. Ciência Rural 2014, 44 (7), 1304-1311. https://doi.org/10.1590/ 0103-8478cr20130971.

15. Barroso L., Viegas C., Vieira J., Ferreira-Pêgo C., Costa J., Fonte P. Lipid-based carriers for food ingredients delivery. J. Food Eng. 2021, 295, 110451. https://doi.org/10.1016/ j.jfoodeng.2020.110451.

16. Emulsion-based Systems for Delivery of Food Active Compounds, Roohinejad S., Greiner R., Oey I., Wen J., Eds., John Wiley \& Sons, Ltd: 2018. https://doi.org/10.1002/9781119247159.

17. Öztürk B. Nanoemulsions for food fortification with lipophilic vitamins: Production challenges, stability, and bioavailability. Eur. J. Lipid Sci. Technol. 2017, 119 (7), 1-18. https://doi.org/ 10.1002/ejlt.201500539.

18. Ferreira C.D., Nunes I.L. Oil nanoencapsulation: development, application, and incorporation into the food market. Nanoscale Res. Lett. 2019, 14 (1), 9. https://doi.org/10.1186/s11671-018-2829-2.

19. McClements D.J. Food Emulsions, CRC Press: 2015. https://doi.org/10.1201/b18868.

20. Kim W., Wang Y., Selomulya C. Dairy and plant proteins as natural food emulsifiers. Trends Food Sci. Technol. 2020, 105 (November), 261-272. https://doi.org/10.1016/j.tifs.2020.09.012.

21. Tucker G. Applications of Rheological Data Into the Food Industry. In Advances in Food Rheology and Its Applications, Elsevier: 2017, pp 159-175. https://doi.org/10.1016/B978-0-08100431-9.00007-3.

22. McClements D.J. The rheology of emulsion-based food products. In Texture in Food, Elsevier Inc.: 2003, Vol. 1, pp 3-35. https://doi.org/10.1533/9781855737082.1.3.

23. Fathi M., Vinceković M., Jurić S., Viskić M., Režek Jambrak A., Donsì F. Food-Grade Colloidal Systems for the Delivery of Essential Oils. Food Rev. Int. 2021, 37 (1), 1-45. https://doi.org/10.1080/87559129.2019.1687514.

24. Leskauskaite D., Jasutiene I., Malinauskyte E., Kersiene M., Matusevicius P. Fortification of dairy products with vitamin D3. Int. J. Dairy Technol. 2016, 69 (2), 177-183. https://doi.org/ 10.1111/1471-0307.12242.

25. Sharifi F., Jahangiri M. Investigation of the stability of vitamin D in emulsion-based delivery systems. Chem. Ind. Chem. Eng. Q. 2018, 24 (2), 157-167. https://doi.org/10.2298/ CICEQ160408028S.

26. Mehmood T., Ahmed A., Ahmed Z., Ahmad M.S. Optimization of soya lecithin and Tween 80 based novel vitamin D nanoemulsions prepared by ultrasonication using response surface methodology. Food Chem. 2019, 289 (March), 664-670. https://doi.org/10.1016/ j.foodchem.2019.03.112.

27. Mitbumrung W., Suphantharika M., McClements D.J., Winuprasith T. Encapsulation of Vitamin D 3 in Pickering Emulsion Stabilized by Nanofibrillated Mangosteen Cellulose: Effect of Environmental Stresses. J. Food Sci. 2019, 84 (11), 3213-3221. https://doi.org/10.1111/17503841.14835.

28. Diamante L.M., Lan T. Absolute Viscosities of Vegetable Oils at Different Temperatures and Shear Rate Range of 64.5 to $4835 \mathrm{~s}^{-1}$. J. Food Process. 2014, 2014, 1-6. https://doi.org/ $10.1155 / 2014 / 234583$.

29. Walstra P. Principles of emulsion formation. Chem. Eng. Sci. 1993, 48 (2), 333-349. https://doi.org/10.1016/0009-2509(93)80021-H. 
30. Ghosh A.K., Bandyopadhyay P. Polysaccharide-Protein Interactions and Their Relevance in Food Colloids. In The Complex World of Polysaccharides, IntechOpen: 2012, pp 395-08. https://doi.org/10.5772/50561.

31. Goh K.K.T., Teo A., Sarkar A., Singh H. Milk protein-polysaccharide interactions. In Milk Proteins, Elsevier: 2020, pp 499-535. https://doi.org/10.1016/B978-0-12-815251-5.00013-X.

32. Dickinson E. Interfacial structure and stability of food emulsions as affected by proteinpolysaccharide interactions. Soft Matter 2008, 4, 932-942. https://doi.org/10.1039/b800106e.

33. Leskauskaite D., Jasutiene I., Kersiene M., Malinauskyte E., Matusevicius P. The Effect of Carboxymethyl Cellulose on the Stability of Emulsions Stabilized by Whey Proteins under Digestion in vitro and in vivo. Int. J. Biol. Food, Vet. Agric. Eng. 2013, 7 (7), 248-253.

34. Seo T., Lee I., Chun Y., Park D., Lee S., Kim B. Improved Stability of Polyglycerol Polyricinoleate-Substituted Nanostructured Lipid Carrier Cholecalciferol Emulsions with Different Carrier Oils. J. Food Sci. 2019, 84 (4), 782-791. https://doi.org/10.1111/17503841.14423.

35. Gubsky S.M., Muzyka S.M., Foshan A.L., Evlash V. V., Kalugin O.N. Reologic properties of aqueous solutions of agar and gelatine for confectionery. Kharkiv University Bulletin. Chemical Series. 2018, 31 (54), 64-78. https://doi.org/10.26565/2220-637X-2018-31-06.

36. National standard of Ukraine. DSTU 4560:2006. Mayonnaise. Acceptance rules and test methods, 2008.

37. Willenbacher N., Georgieva K. Rheology of Disperse Systems. In Product Design and Engineering: Formulation of Gels and Pastes, Wiley-VCH Verlag GmbH \& Co. KGaA: 2013, pp 7-49. https://doi.org/10.1002/9783527654741.ch1.

38. Kirsanov E.A., Matveenko V.N. Non-Newtonian behavior of structured systems, Technosphera: 2016.

39. Matveenko V.N., Kirsanov E.A. Structural Viscosity and Structural Elasticity of Polymer Melts. Russ. J. Appl. Chem. 2018, 91 (5), 839-865. https://doi.org/10.1134/S1070427218050166.

40. Matveenko V.N., Kirsanov E.A. The viscosity and structure of dispersed systems. Moscow Univ. Chem. Bull. 2011, 66 (4), 199-228. https://doi.org/10.3103/S0027131411040079.

41. Kirsanov E.A., Matveenko V.N. The flow of emulsions as structural systems. Liq. Cryst. their Appl. 2008, 1 (23), 14-23.

42. Casson N. A flow equation for pigment-oil suspensions of the printing ink type. In Rheology of Disperse Systems, Mill C.C., Ed., Pergamon Press: 1959, pp 84-104.

43. Cross M.M. Rheology of non-newtonian fluids: A new flow equation for pseudoplastic systems. J. Colloid Sci. 1965, 20 (5), 417-437. https://doi.org/10.1016/0095-8522(65)90022-X.

44. Matveenko V.N., Kirsanov E.A. Structural rationale of a non-Newtonian flow. Moscow Univ. Chem. Bull. 2017, 72 (2), 69-91. https://doi.org/10.3103/S0027131417020031.

45. Kirsanov E.A., Matveenko V.N. Analysis of coefficients of the generalized flow equation. Liq. Cryst. their Appl. 2012, 1 (39), 21-30.

46. Tadros T.F. Use of Rheological Measurements for Assessment and Prediction of the Long - Term Physical Stability of Formulations. In Rheology of Dispersions: Principles and Applications, Wiley-VCH Verlag GmbH \& Co. KGaA: 2010, pp 169-192. https://doi.org/10.1002/ 9783527631568.

47. Herrera M.L. Analytical Techniques for Studying the Physical Properties of Lipid Emulsions, SpringerBriefs in Food, Health, and Nutrition, Springer US: 2012, Vol. 3. https://doi.org/10.1007/978-1-4614-3256-2.

48. Gbassi G., Yolou F., Sarr S., Atheba P., Amin C., Ake M. Whey proteins analysis in aqueous medium and in artificial gastric and intestinal fluids. Int. J. Biol. Chem. Sci. 2012, 6 (4). https://doi.org/10.4314/ijbcs.v6i4.38.

49. Tan T.J., Wang D., Moraru C.I. A physicochemical investigation of membrane fouling in cold microfiltration of skim milk. J. Dairy Sci. 2018, 97 (8), 4759-4771. https://doi.org/ 10.3168/jds.2014-7957.

50. Hettiarachchy N., Kannan A., Schafer C., Wagner G. Gelling of Plant Based Proteins. In Product Design and Engineering: Formulation of Gels and Pastes, Wiley-VCH Verlag GmbH \& Co. KGaA: 2013, pp 221-244. 
51. Amagliani L., Regan J.O., Kelly A.L., Mahony J.A.O. Trends in Food Science \& Technology The composition, extraction, functionality and applications of rice proteins : A review. Trends Food Sci. Technol. 2017, 64, 1-12. https://doi.org/10.1016/j.tifs.2017.01.008.

52. Liu S., Elmer C., Low N.H., Nickerson M.T. Effect of pH on the functional behaviour of pea protein isolate - gum Arabic complexes. Food Res. Int. 2010, 43 (2), 489-495. https://doi.org/10.1016/j.foodres.2009.07.022.

53. Romero A., Beaumal V., David-briand E., Cordobes F., Guerrero A., Anton M. Food Hydrocolloids Interfacial and emulsifying behaviour of rice protein concentrate. Food Hydrocoll. 2012, 29 (1), 1-8. https://doi.org/10.1016/j.foodhyd.2012.01.013.

54. Malinauskyte E., Ramanauskaite J., Leskauskaite D., Devold T.G., Schüller R.B., Vegarud G.E. Effect of human and simulated gastric juices on the digestion of whey proteins and carboxymethylcellulose-stabilised $\mathrm{O} / \mathrm{W}$ emulsions. Food Chem. 2014, 165, 104-112. https://doi.org/10.1016/j.foodchem.2014.05.078.

55. Kruif C.G. De, Weinbreck F., Vries R. De. Complex coacervation of proteins and anionic polysaccharides. Curr. Opin. Colloid Interface Sci. 2004, 9, 340-349. https://doi.org/10.1016/j.cocis.2004.09.006.

56. Dickinson E. Food Hydrocolloids Mixed biopolymers at interfaces : Competitive adsorption and multilayer structures. Food Hydrocoll. 2011, 25, 1966-1983. https://doi.org/10.1016/ j.foodhyd.2010.12.001.

57. Blijdenstein T.B.J., Winden A.J.M. Van, Vliet T. Van, Linden E. Van Der, Aken G.A. Van. Serum separation and structure of depletion- and bridging-flocculated emulsions : a comparison. Colloids Surfaces A Physicochem. Eng. Asp. 2004, 245, 41-48. https://doi.org/10.1016/j.colsurfa.2004.07.002.

Надіслано до редакиії 29 вересня 2020 р.

С.М. Губський ${ }^{\star}$ О.Ф. Аксьонова* ${ }^{*}$ В.В. Євлаш, А.С. Батрак ${ }^{\dagger}$, А.М. Лагута ${ }^{\dagger}$, О.М. Калугін ${ }^{\dagger}$. Дизайн, реологія та мікроструктура систем на основі харчових емульсій для доставки вітаміну Д.

* Харківський державний університет харчування та торгівлі, кафедра хімії, мікробіології та гігієни харчування, вул. Клочківська, 333, 4, Харків, 61051, Україна

† Харківський національний університет імені В.Н. Каразіна, хімічний факультет, кафедра неорганічної хімії, майдан Свободи, 4, Харків, 61022, Україна

Збагачення харчових продуктів вітаміном D має кілька обмежень, оскільки ці сполуки можуть розкладатися або зазнавати небажаних змін під час технологічної обробки і зберігання. Метою цієї публікації було дослідження реологічних властивостей і мікроструктури емульсій для збагачення харчових продуктів вітаміном $\mathrm{D}_{3}$. В якості таких емульсій використовували емульсії типу масло-в-воді, що були стабілізовані сумішшю різних білків (ізоляти сироваткового білка, сухого знежиреного молока та суміші рослинних білків) в якості емульгаторів і карбоксиметилцелюлози як загусника. Експериментально було визначено напругу зсуву й ефрективну динамічну в'язкість емульсій в широкому діапазоні швидкостей зсуву. Апроксимацією експериментальних кривих течії за допомоги степеневого рівняння були розраховані значення коефіцієнта консистенції і показника текучості. Отримані дані дозволили класифікувати емульсії як рідини з псевдопластичним плином.

В рамках структурного підходу реологічні дані були проаналізовані на основі узагальненої реологічні моделі Кессона. Розраховані з експериментальних даних вклади в процес в'язкої течії від інтегральних характеристик асоціатів макромолекул та окремих частинок при їх гідродинамічній взаємодії дозволили пояснити ефект зміни в'язкості емульсій від природи використовуваного емульгатора.

Дослідження дзета потенціалу методом динамічного розсіювання світла показало наявність сил електростатичного відштовхування крапель емульсії як фрактора стабільності цих емульсій. Знак потенціалу і його величина вказують на процес адсорбції на поверхні жирових крапель молекул білка. Наявність піку фрлокульованих частинок на гістограммах розподілу часток за розмірами пояснено присутністю в водної фразі емульсії неадсорбованих молекул полісахариду, які здатні генерувати агрегацію крапель емульсії за механізмом стоншення подвійного електричного шару.

Незалежно від вибору типу і природи білкових емульгаторів - тваринного або рослинного походження, всі досліджені системи були стабільні і можуть бути розглянуті в якості емульсійних систем доставки вітаміну D в організм людини разом з споживаними продуктами. 3 економічної точки зору доцільно використання в якості емульгатора сухе знежирене молоко. Отримані емульсії можуть бути використані як основа для виробництва збагачених вітаміном $\mathrm{D}_{3}$ продуктів харчування, зокрема, молочних продуктів.

Ключові слова: реологія, білок, емульсія, система доставки, вітамін Д, структурний підхід. 
С.М. Губский, Е.Ф. Аксенова*, В.В. Евлаш, А.С. Батрак ${ }^{\dagger}$, А.Н. Лагута ${ }^{\dagger}$, О.Н. Калугин ${ }^{\dagger}$. Дизайн, реология и микроструктура систем на основе пищевых эмульсий для доставки витамина Д.

* Харьковский государственный университет питания и торговли, кафедра химии, микробиологии и гигиены питания, ул. Клочковская, 333, Харьков, 61051, Украина

† Харьковский национальный университет имени В.Н. Каразина, химический фракультет, кафедра неорганической химии, пл. Свободы, 4, Харьков, 61022, Украина

Обогащение пищевых продуктов витамином D имеет несколько ограничений, поскольку эти соединения могут разлагаться или претерпевать нежелательные изменения во время технологической обработки и хранения. Целью этой публикации было исследование реологических свойств и микроструктуры эмульсий для обогащения пищевых продуктов витамином $\mathrm{D}_{3}$. B качестве таких эмульсий использовали эмульсии типа масло-в-воде, стабилизированные смесью разных белков (изоляты сывороточного белка, сухого обезжиренного молока и смеси растительных белков) в качестве эмульгаторов и карбоксиметилцеллюлозы в качестве загустителя. Экспериментально были определены напряжение сдвига и эффективная динамическая вязкость эмульсий в широком диапазоне скоростей сдвига. Аппроксимацией экспериментальных кривых течения с помощью степенного уравнения были рассчитаны значения коэффициента консистенции и показателя текучести. Полученные данные позволили классифицировать эмульсии как жидкости с псевдопластическим течением.

В рамках структурного подхода реологические данные были проанализированы на основе обобщенной реологической модели Кэссона. Рассчитанные из экспериментальных данных вклады в процесс вязкого течения от интегральных характеристик ассоциатов макромолекул и отдельных частиц при их гидродинамическом взаимодействии позволили объяснить эфффект изменения вязкости эмульсий от природы используемого эмульгатора.

Исследование дзета потенциала методом динамического рассеивания света показало наличие сил электростатического отталкивания капель эмульсии как фактора стабильности этих эмульсий. Знак потенциала и его величина указывают на процесс адсорбции на поверхности жировых капель молекул белка. Наличие пика флоккулированных частиц на гистограммах распределения частиц по размерам объяснено присутствием в водной фазе эмульсии неадсорбированных молекул полисахарида, которые способны генерировать агрегацию капель эмульсии по механизму утончения двойного электрического слоя.

Независимо от выбора типа и природы белковых эмульгаторов - животного или растительного происхождения, все исследованные системы были стабильны и могут быть рассмотрены в качестве эмульсионных систем доставки витамина D в организм человека вместе с потребляемыми продуктами. С экономической точки зрения целесообразно использование в качестве эмульгатора сухого обезжиренного молока. Полученные эмульсии могут быть использованы как основа для производства обогащенных витамином $\mathrm{D}_{3}$ продуктов питания, в частности, молочных продуктов.

Ключевые слова: реология, белок, эмульсия, система доставки, витамин Д, структурный подход.

Kharkiv University Bulletin. Chemical Series. Issue 35 (58), 2020 